\section{An overview and future prospects of Croatian geotechnological heritage}

Rudarsko-geološko-naftni zbornik

(The Mining-Geology-Petroleum Engineering Bulletin) UDC: 679.8: 622

DOI: 10.17794/rgn.2021.1.7

\author{
Zlatko Briševac'; Ana Maričić ${ }^{\text {; }}$ Vladislav Brkić3; Vladi Bralić ${ }^{4}$ \\ ${ }^{1}$ University of Zagreb, Faculty of Mining, Geology and Petroleum Engineering, https://orcid.org/0000-0001-7810-8255 \\ ${ }^{2}$ University of Zagreb, Faculty of Mining, Geology and Petroleum Engineering, http://orcid.org/0000-0002-9082-9917 \\ ${ }^{3}$ University of Zagreb, Faculty of Mining, Geology and Petroleum Engineering, https://orcid.org/0000-0003-2075-1832 \\ ${ }^{4}$ Arhitektonsko-građevinski atelje d.o.o., Ive Marinkovića 14, 51000 Rijeka
}

\begin{abstract}
Industrial heritage plays an important role in the economical, historical, and cultural identity of contemporary European society. A significant part of the industrial heritage consists of historical buildings which have remained after mining and petroleum exploitation. Moreover, industrial heritage can be also nurtured in countries in which mining and petroleum activities are not fully developed. It is inevitably associated with geological heritage. Furthermore, geological heritage is essential for a better understanding of nature, its wider appreciation and better protection. Mining has always played a significant industrial role, but it has recently lost its significance due to increasing environmental requirements regarding the European green deal and transforming the economy for a sustainable future. However, old mining and petroleum heritage sites can become attractions and they can contribute to the development of tourism and the community itself. A new term "geotechnological heritage", presented in this paper, is related to mining, geological and petroleum heritage due to their significant interaction. This paper presents the used and unused touristic potential of heritage on selected sites in the Republic of Croatia. In addition, an analysis of the Croatian undervalued geotechnological heritage has been performed after the exploitation of stone and other nonmetallics, coal, metals, and petroleum. Unlike Croatia, the potential of geotechnological heritage has been recognized and exploited in most European countries. Therefore, Croatia has a great opportunity to develop heritage based on the experience of more successful members of the European Union.
\end{abstract}

\title{
Keywords:
}

geotechnological heritage; mining heritage; geological heritage; petroleum heritage; industrial heritage

\section{Introduction}

According to UNESCO, heritage is our legacy from the past. We live with it today and pass it on to future generations. Our cultural and natural heritage are both irreplaceable sources of life and an inspiration that we should cherish, protect, and learn about. There are one hundred and eighteen protected mining related properties located in sixty-three countries which are inscribed on the UNESCO World Heritage List. Protected areas are classified into three categories with sixty-six of them being in cultural, forty-two in natural and ten in mixed categories. There are forty-one mining properties located in seventeen European countries (URL1).

In addition to the UNESCO World Heritage List from the end of the 1980s, the Council of Europe has initiated a project called the European Cultural Route. Its aim is to make the Europeans aware of their cultural identity and encourage them to preserve and protect heritage as a source of social, economic, and cultural development of the places in which they live. At the same time, the pur-

Corresponding author: Zlatko Briševac

zlatko.brisevac@rgn.hr pose of the project is to stimulate places involved in cultural tourism to retain sustainable development. Croatia is represented with four non-mining related sites on the European Route of Industrial Heritage - ERIH (URL2). Although Croatia has a very long mining tradition and its potential places are shown in this paper, unfortunately mining related properties are not on the ERICH list. In addition, the project that needs to be mentioned is "MineHeritage: Historical Mining - Tracing and Learning from Ancient Materials and Mining Technology". Old mining sites in eleven European countries including Croatia will be listed and described (URL3) in the referred project.

Mining as an important factor of economic and social development has played a crucial role in Europe's industrial history over the centuries. If raw materials, such as stone, metals (copper, iron, silver), salt, coal, petroleum and others, were not extracted, the development path of the continent would have looked completely different. However, the modern world is constantly changing in economic, social, ecological, and/or cultural directions. These changes represent complex processes that cities, specific regions, and governments across the civilized 
world are currently facing and that affect the mining industry. For example, in the former socialist countries of Central and Eastern Europe, the regime change in $1989 / 90$ brought about a radical turning point. When the system collapsed, many industries faced ruin and mining was not an exception (Wirth et al., 2012). The consequences of the social and civilizational progress once caused by the use of coal, and in today's world by oil, should not be neglected in industrial heritage research (Freese, 2006). In addition, the history of the European and Croatian oil and gas industry, similarly, has an impact on local, as well as on global political events, economic constraints, and personal endeavours of individual geoscientists, as much as it does on the development of technologies and regional geology. The establishment of petroleum as a tradable commodity, as well as a natural resource, has greatly changed the history of civilization, thus introducing a new set of values, opportunities and forces. It has also had a great impact on science, technology, energy production and consumption, and it has improved living standards throughout the world (Craig et al., 2018).

Accordingly, given the fact that many mineral resources were once exploited in Croatia, the main goal was to present the wealth of mining and petroleum industrial heritage that remains after extensive historical exploitation. In addition, there is a lack of distinctive nomenclature that unites and refers only to mining and petroleum heritage and connected geological heritage. The term industrial heritage covers a wider range of historical activities associated with various industries that ordinarily do not retain common links. There is a need for one specific name that would refer to the heritage associated with mining and petroleum exploitation and geology. This would contribute to greater visibility and tourism branding for this type of heritage. Therefore, in this paper, we have introduced a new term, "geotechnological heritage," which covers mining, petroleum and geological heritage.

\section{European geotechnological heritage}

There are many examples of the successful conservation and revitalization of mining heritage sites in the European Union. In some classical cases, old mines formerly used for the extraction of salt have been revitalized. Traditionally, this is the case of Saltzburg or the famous Wieliczka salzmine near Krakow (see Figure 1). Wieliczka is the most popular visitor mines in the world and one of the most visited tourist attractions in Poland. It is marked as the first of the mining objects and regions in the world on the UNESCO World Heritage List (URL1). Comparing the number of visitors, it ranks higher than the Austrian Hallstatt, which is probably the oldest salt mine in the world. The history of salt mining dates back to the Middle Bronze Age and it is related to the Swedish Falun (which once belonged to the most im-

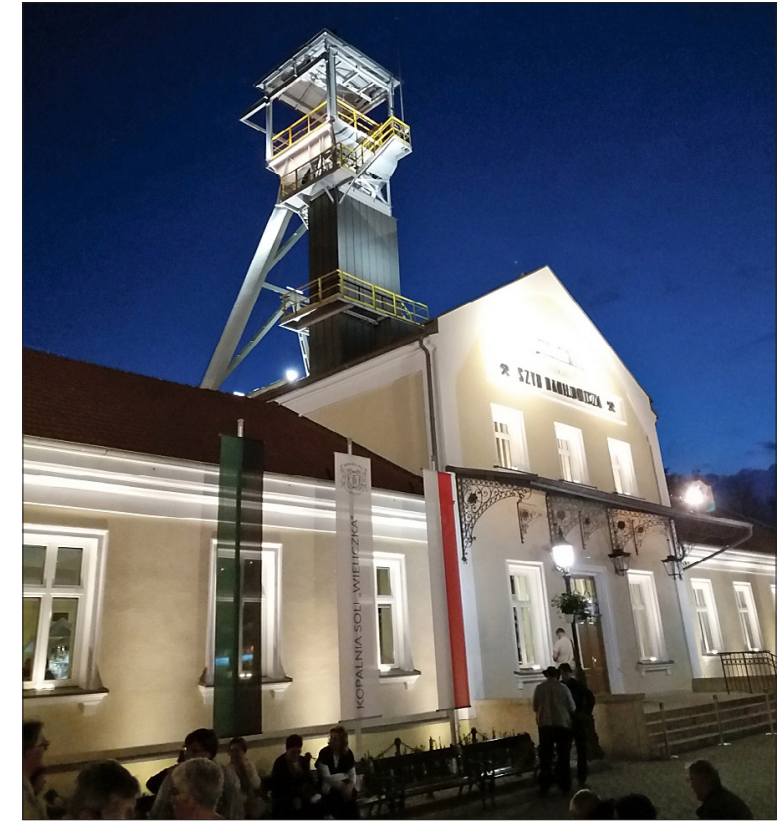

Figure 1: Salt mine entrance in Wieliczka

(by Briševac, Z.)

portant copper mining areas in the world), and the Columbian Zipaquirá, which is the largest salt deposit in the world (Rybár and Hronček, 2017).

Zloty Stok Gold Mine (Poland) is one of the abandoned mines which was revitalized by local people further to the revitalization plan from 1991. Today, this old mining site offers numerous attractions to tourists. The most interesting attraction is an underground mine route, the Museum of Mining and Metallurgy and Medieval Technology Park. Similarly, volunteers have played an important role in the revitalization process of the King Edward Mine Museum in Cornwall (United Kingdom). There they restored a tin processing mill from 1900 to full working order. This mill is the only one of that kind. In addition, local communities and civil societies can have an important role in the revitalization of old mining sites such as La Tortilla Mine in Linares (Spain) (Kaźmierczak et al., 2019). A great example of how cooperation and a joint effort between mine owners and local authorities have contributed to the revitalization process of old mining sites is the Lousal Mine in Portugal, where the Mining Museum and the Science Centre are open for visitors (Inácio et al., 2013). Furthermore, Europe's largest open pit mine is the Parque de Minero de Riotinto and it presents a rich mining history of that part of Spain.

In some cases, mining heritage is only a part of industrial facilities, as in case of the Styrian Iron Road in Austria and the Lavrion Technological and Cultural Park in Greece. Lavrion is an example of a once over-industrialized city, which has recovered and adapted to new standards of modern development since the local industry ceased to dominate in 1989. Industrial heritage has contributed to the reusage and development of museum 
Table 1: List of petroleum and gas museums in Europe (Kruczek and Kruczek, 2016)

\begin{tabular}{|l|l|l|l|}
\hline Museum & Country & Established & Exhibition \\
\hline $\begin{array}{l}\text { National Museum of Oil Industry, } \\
\text { Ploesti }\end{array}$ & Romania & 1957 & A collection of machines and tools. \\
\hline $\begin{array}{l}\text { Museum of Oil and Gas Industry, } \\
\text { Bóbrka }\end{array}$ & Poland & 1961 & $\begin{array}{l}\text { A collection of objects and documents connected } \\
\text { with the oldest oil petroleum mine. }\end{array}$ \\
\hline $\begin{array}{l}\text { Museum of the Hungarian Oil } \\
\text { Industry, Zalaegerszeg }\end{array}$ & Hungary & 1969 & Machines connected to the extraction of crude oil. \\
\hline $\begin{array}{l}\text { Musée du pétrole de Merkwiller- } \\
\text { Pechelbronn }\end{array}$ & France & 1967 & $\begin{array}{l}\text { A collection of documents, photos, models, exhibits } \\
\text { and oil industry equipment. }\end{array}$ \\
\hline $\begin{array}{l}\text { German Petroleum Industry, Wiese } \\
\text { Scottish Shale Oil Mines Light } \\
\text { Railway, Almond Valley Heritage } \\
\text { Centre, Millfield }\end{array}$ & Germany & 1970 & $\begin{array}{l}\text { A collection including derricks, valves, pumps } \\
\text { and the 'nodding donkeys' used to extract crude oil. }\end{array}$ \\
\hline $\begin{array}{l}\text { Oljeon. Analberg, Oil island } \\
\text { in Lake Amannigen }\end{array}$ & Sweden & 1986 & $\begin{array}{l}\text { Exhibits presenting the history of the petroleum industry, } \\
\text { and the starting point for a heritage trail that passes } \\
\text { through shale-working villages. }\end{array}$ \\
\hline $\begin{array}{l}\text { Museum of the Petroleum Industry, } \\
\text { Stavanger }\end{array}$ & Norway & 1999 & $\begin{array}{l}\text { A refinery dating from the first years of the petroleum } \\
\text { industry, preserved at Angelsberg on Oljeon (oil island) } \\
\text { in Lake Amannigen. }\end{array}$ \\
\hline $\begin{array}{l}\text { Oil Shale Museum Kaevanspark, } \\
\text { Jaama }\end{array}$ & Estonia & 2001 & $\begin{array}{l}\text { An exhibition presenting the technology of oil exploration } \\
\text { and the way of life of those who worked on the platforms. }\end{array}$ \\
\hline
\end{tabular}

premises which coexist with new scientific and research premises (Cheirchanteri, 2019).

Not only mining heritage, but also museums, memorials, and other historical buildings have contributed to the importance of the petroleum industry in European culture. For example, several European countries, such as France, Germany and Italy, cherish petroleum heritage, which is abundant in inventions and technology, although the referred countries have never achieved significant levels of conventional oil production (Craig et al., 2018). Nowadays, these sites have become important tourist attractions together with a geotechnological heritage. This refers to abandoned oil fields, workshops, buildings, construction, vehicles, machines, tools, scientific instruments, documentation, etc. The production and processing of petroleum was added to the ERIH system of tourist routes which are connected with energy. The most important oil and gas exploration and production museums established in Europe are presented in Table 1 (Kruczek and Kruczek, 2016).

The most successful example of using an old petroleum site is the German petroleum museum grounds which consist of an area of $18000 \mathrm{~m}^{2}$ and represent the former oil field placed near the city of Hanover. At the end of the production era, the Petroleum Museum Wiese was established by the Deutsche Erdöl AG (DEA), which re-opened as a public museum in 1970. There are over sixty-five known wells on the site (Douet, 2019).

\section{Croatian geotechnological heritage}

Many mineral raw materials were exploited in Croatia during the past, with a special emphasis on stone quarrying. Today, stone (natural building or dimension stone and aggregate) represents the most important raw material in Croatia. Besides stone, gravel pits or clay pits are very often places of surface mining. Intensive exploitation of metal ores was recorded in the Middle Ages. In addition, there has been a significant exploitation of coal as a fossil material for energy, which has been replaced by the petroleum industry and has had a long tradition in Croatia as well. Geotechnological heritage is based on the tradition of exploitation, and the places of preserved Croatian geotechnological heritage are shown in Figure 2.

\subsection{Stone quarrying and the excavation of industrial minerals}

Stone quarrying and utilization can be characterized as the oldest human activities known in ancient civilizations around the world. Croatia is not an exception in that field. It has a very long tradition of stone exploitation where sedimentary rocks, mostly limestone, have been exploited. Consequently, natural building stone represents the most important mineral raw material in Croatia, not only today, but also during history since the ancient times, through the Middle Ages, and to this day (Crnković and Jovičić, 1993; Fio Firi and Maričić, 2020). Today, forty-four different varieties of natural stone are exploited in Croatia in the shape of marketable stone blocks or slabs (HRN EN 12440, 2017).

The stone has been quarried along the Adriatic coast from Istria through Dalmatia to Dubrovnik, especially on the islands of Brač and Korčula, as well as in the inland near Varaždin and on Medvednica Mt. (Crnković and Jovičić, 1993; Donelli et al., 2009; Parica, 2014; 


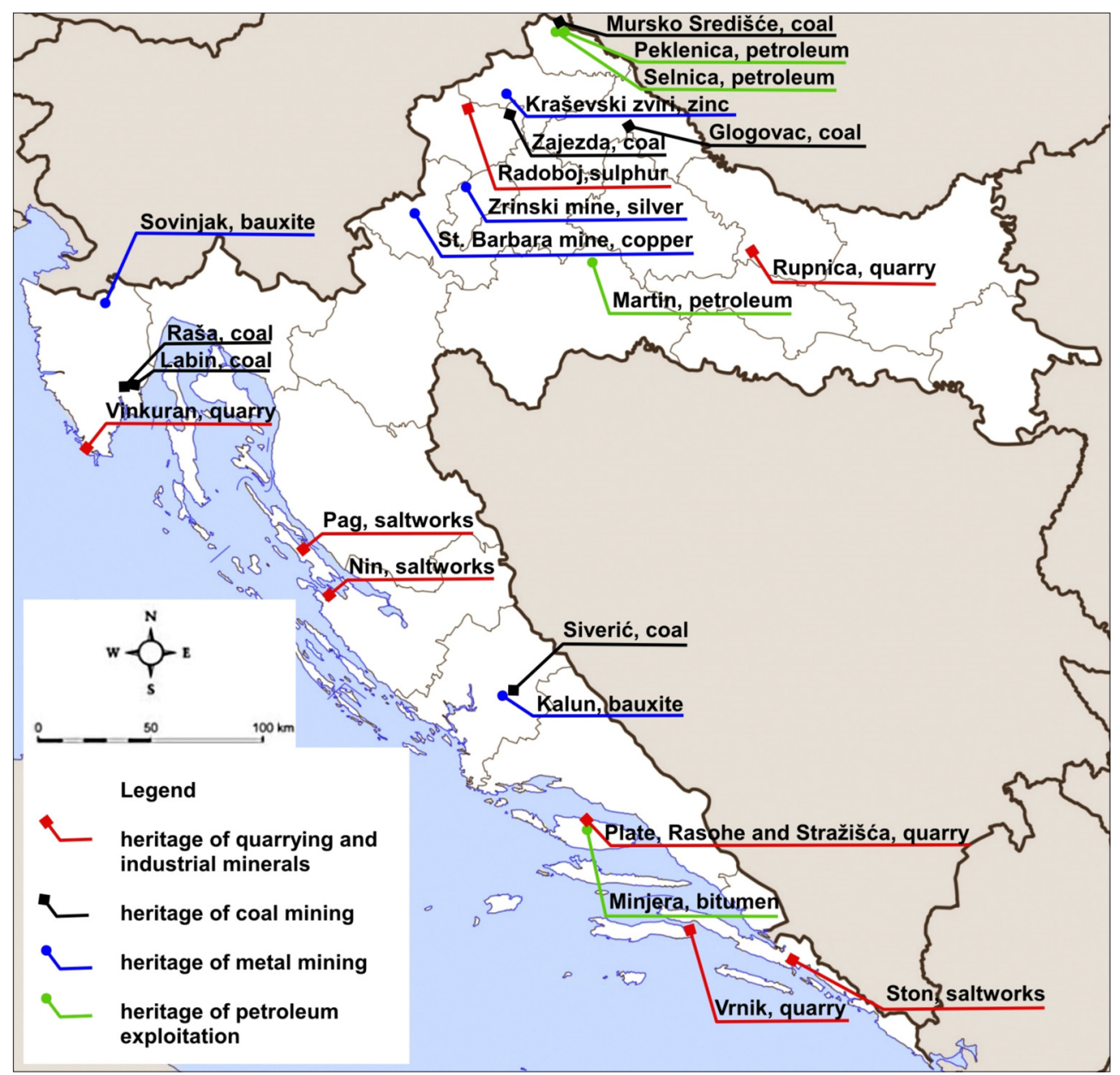

Figure 2: Map of Croatian geotechnological heritage

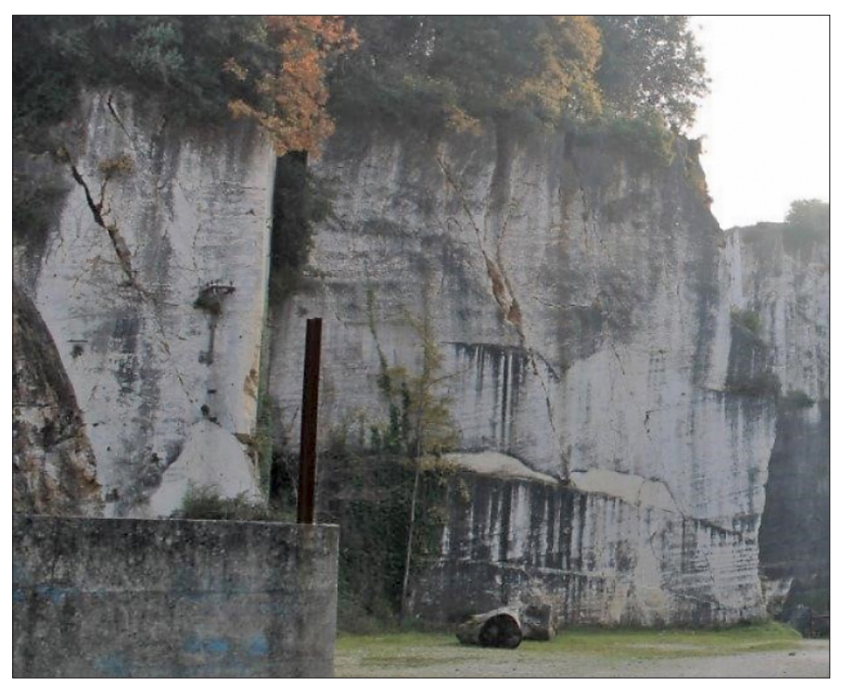

Figure 3: Old quarry fronts in Vinkuran quarry (by Maričić, A.)

Kovačević Zelić et al., 2020). The knowledge of quarrying activity in ancient Histria and Dalmatia lies within larger economic and cultural centers of the referred provinces. Highly developed construction and artistic techniques from that time have been used today. On the eastern Adriatic coast, we come across antique monuments built of local stone. Stone from each individual quarry has its own characteristics and quality (Buzov, 2009).

Due to a famous and long tradition of stone exploitation and stonemasonry, today there are an extremely large number of abandoned natural stone quarries in Croatia. These old mining sites are often neglected although many of them could be revitalized and used as potential tourist sites, especially for geo-tourist purposes. Their excavation history and used technology, the cultural heritage they are associated with, but also their different and unique geological features could be presented to visitors as part of a geo-tourist tour (Mileusnić et al., 2019).

Unfortunately, there are only a few examples of good practice in Croatia where old, abandoned quarries could be revitalized and used in a new way (Mileusnić et al., 2019). One of the rare examples of such good practice is the old quarry Rupnica near Voćin. Rupnica quarry was declared to be the first protected geological heritage monument in Croatia in 1948. Nowadays, it is a part of Papuk Geopark and was designated as part of UNESCO Global Geoparks (Žeger Pleše and Zwicker Kompar, 2020). Another good practice example is Vinkuran quar- 
ry (see Figure 3) near Pula in Istria. Vinkuran is also called "Cavae Romane" because it was the oldest quarry in Istria, which was active during ancient times. Upper Cretaceous rudist limestone was quarried and used for construction of the outer mantle of the Arena in Pula (Crnković, 1991).

Traces of old exploitation with hand tools or chisel marks that looks like a "fish bone" are visible on open quarry fronts. For that reason, Vinkuran quarry nowadays represents an open-air monument of human mining activity (Mileusnić et al., 2019). In addition, the quarry is easily reachable and well maintained. Because of its vicinity to the town of Pula, it used as a stage for various performances and concerts.

Apart from the above referred quarries, the oldest ones from Roman times are on the island of Brač, at locations in Plate, Rasohe and Stražišća, located near the villages of Škrip and Splitska (Didolić, 1957). In the Rasohe quarry, there is a relief of Hercules which is carved into a rock front and in the Plate quarry, a covenant altar was found with an inscription that mentions the soldier Valerius Valerianus (Cambi, 2013). In these quarries, handmade toolmarks on quarry-faces and separation trenches called "pasharins" have been preserved (Russell and Glicksman, 2015) for the extraction of large blocks. Today there is a $2 \mathrm{~km}$ long path arranged and managed by the local community for visitors to reach the Rasohe quarry and to enjoy in the view of the Hercules relief. Apart from the island of Brač, the long tradition of mining and stonemasonry on the island of Korčula and especially the Lumbarda area should be emphasized. Exceptionally high-quality stone varieties have been quarried on the nearby islets called Vrnik (see Figure 4), Sutvara, Kamenjak and others since antiquity and used in the old towns of Korčula and Dubrovnik (Gjivoje, 1970; Russell and Glicksman, 2015; Mileusnić et al., 2019).

In addition to quarried stone, salt as a non-metallic mineral was also produced on the Adriatic coast. The Ston saltwork is the oldest in Europe and the largest preserved in the history of the Mediterranean. The diocese of Ston is mentioned in 877 , so it is assumed that it is the oldest diocese of the Croatian ethnic area (Bogdan, 2018). Besides Ston saltworks, the most intensive tradition of salt extraction is present on the island of Pag, which dates back to the 8th and 9th centuries (Brgles, 2014). Today, three saltworks still produce salt, Ston (see Figure 5), Pag, as well as Nin saltwork (URL4).

In addition, sulfur of excellent quality was being extracted in Radoboj in the past. The sulfur mine was opened in 1811 (Bićanić, 1951). Many plant fossils, insects and fish were found there, and they all represent an exceptional ex-situ geological heritage (Mileusnić et al., 2019). Among many fossils it is important to mention the famous and the oldest found leaf of a vine (Vitis teutonica) and many fossil insects, such as ants, flies, and leaf bugs (Kozina, 2014). Additionally, a sulfur re-

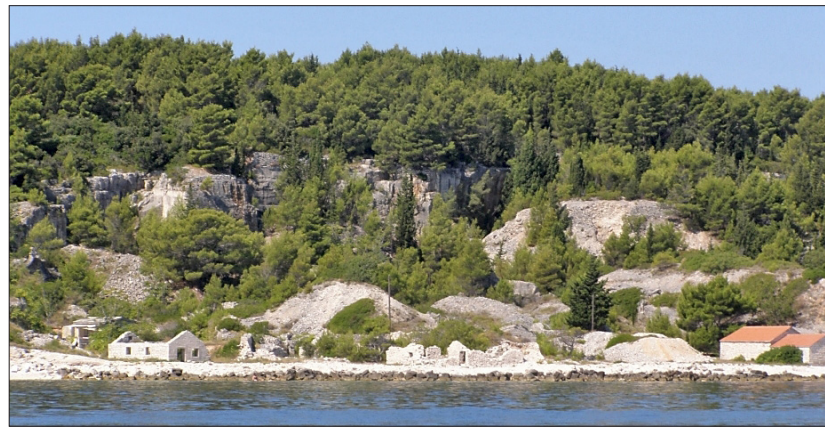

Figure 4: Remains of the old quarry on the Vrnik islet near Lumbarda (by Maričić, A.)

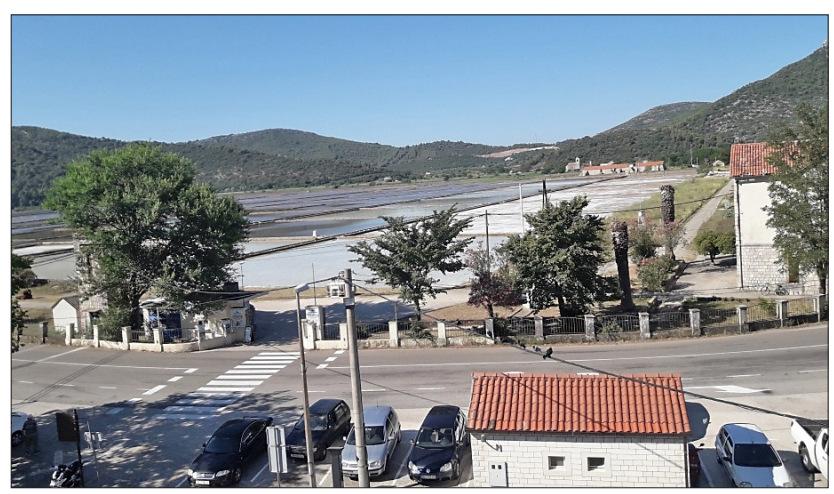

Figure 5: Saltworks in Ston (by Briševac, Z.)

fining machine known as the "Radoboj machine" was invented and used for the first time in Radoboj (Kišpatić, 1878) which has contributed to the importance of the mining heritage. Today, this sulfur mine does not exist anymore (see Figure 6). Therefore, only old documents and an essential fossil collection prove the importance of the geological and mining heritage of this area. Due to the exceptional importance of mining and sulfur exploitation in the Radoboj area, the Radboa Museum was opened (URL5). The museum was partly funded by European funds and represents a good example of connect-

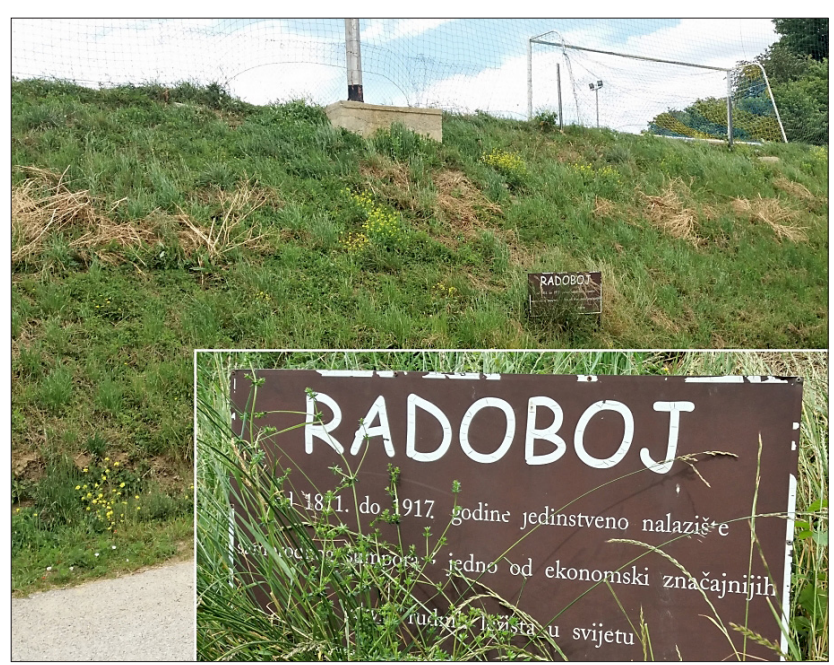

Figure 6: Marking of the place where the sulfur mine was (by Briševac, Z.) 
ing mining and geoheritage with the European perspective of energy efficiency and educational contents.

\subsection{Coal mining}

In Croatia, coal was being periodically and to a lesser extent extracted in many places, but intense exploitation took place in Istria, Zagorje, Bilogora, Međimurje and in some places in Dalmatia.

Coal mining in Istria ceased in the early 1990s. The local community still has a strong memory of this industry, and many of its historical artefacts have remained on the peninsula. Some towns like Labin (see Figure 7) are heavily marked by them.

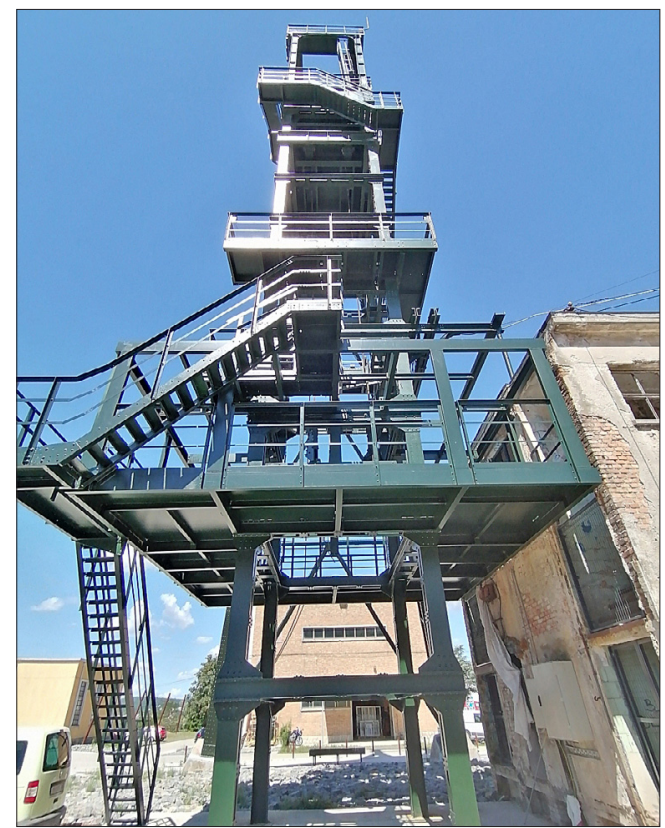

Figure 7: Mine shaft in Labin (by Briševac, Z.)

The first known coal mining concession dates back to 1626 and it was issued in the vicinity of the town of Labin. The bituminous coal type was used then to coat the underwater parts of ships. Continuous production started in 1785 at the "Pegola Nera" mine above Krapno (Vujec, 1997). Later, a hard coal type was found, and its intensive exploitation developed. The coal has been generally known under the name of Raša coal. It is an exceptional coal from a global point of view due to its high content of organic sulfur, which can be up to $14 \%$ (Medunić et al., 2016). Raša coal was also known for its increased radioactivity. The activity of U-238 was 500$1200 \mathrm{~Bq} / \mathrm{kg}$ in the $1970 \mathrm{~s}$, and $250-300 \mathrm{~Bq} / \mathrm{kg}$ in the 1980s, which was 10-15 times higher than the average of other types of coal in the world (Marović et al., 2004).

When the exploitation of coal finished in Labin, the "Art Association Labin Art Express" (URL6) began to operate successfully, presenting its ideas for the revitalization of the mine for many years. It is recognized as such and it has participated as a partner in many Euro- pean projects. The local city authorities of the town of Labin have been involved in three significant projects related to the former mines: KOVA Mining Heritage Conversion Project (URL7), MIN-HER (URL8) and MINE TOUR (URL9).

The future project Memorial Center Karlota in Raša (URL10) can be included in the spatial revitalization and presentation plan of the entire mining area around the town of Labin. With regard to the authenticity of the architectural and urban heritage of the mining town of Raša, the concept of the Memorial Centre of European Totalitarisms, situated in the nearby abandoned quarry of Karlota (see Figure 8), is based upon the idea of presenting the "spirit of the place" (lat. genius loci), or the identity of place, through a new complex with a specific architecture and urban design. The abandoned quarry Karlota has proven to be an ideal location for many reasons. It is situated in the immediate area surrounding Raša, on an elevated terrain with great views over the town's historical structures. There is a plateau amidst the rock wall with a surface area of about $13900 \mathrm{~m}^{2}$, which meets all the requirements for the complex disposition.

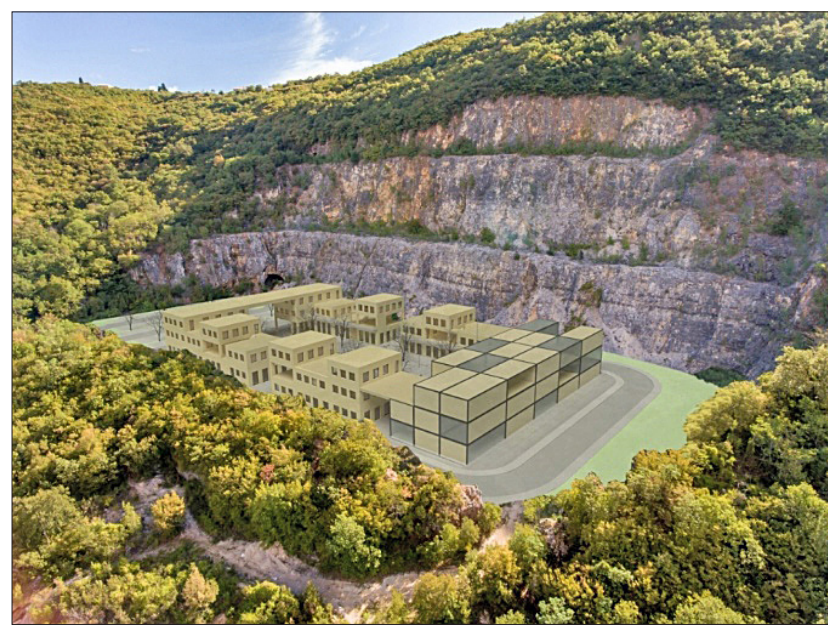

Figure 8: Memorial center Karlota in Raša, architectural visualization (by "Arhitektonsko-građevinski atelje" d.o.o.)

The complex can be easily connected with the abandoned coal mine which was in operation between 1928 and 1966. The team of authors consisting of Vladi Bralić, Arsen Čupev and Luka Ilić, has designed the complex as a certain symbiosis of the cultural and commercial sector. Different educational facilities dedicated to studying European totalitarian regimes would be joined with a number of various commercial facilities in a single architectural envelope. A highly aesthetic synergy of cultural and educational elements has been achieved through this center, but also a variety of shops, gastronomy, and design.

According to the Croatian Encyclopedia (URL11), the first coal mine in the Zagorje region was the Straža mine near Krapina, which opened in 1857. The Ivanec Coal Mine opened in 1867 and had operated efficiently 
since the 1890s. It was one of the oldest and largest lignite coal mines in the local area (Petrić, 2013). Today, mining buildings together with industrial remains such as a mining separator, have a huge potential for revitalization. There have also been some initiatives and actions, but many of them are going to be taken into account by the Tourist Office Ivanec (Jagetić Daraboš, 2017) within next steps of the revitalization process. On the opposite side of Ivanec, namely in the southern part of the mountain Ivančica, the Konjščina basin coal mines were equally developed. A representative monument of the mine is set in Zajezda (Budimština municipality) and it is located next to the chapel of St. Barbara (see Figure 9). The local mine in Zajezda existed from 1928 to 1967. The inspiration for the construction of the mine in the Technical Museum Nikola Tesla in Zagreb stems from the Konšćina mine.

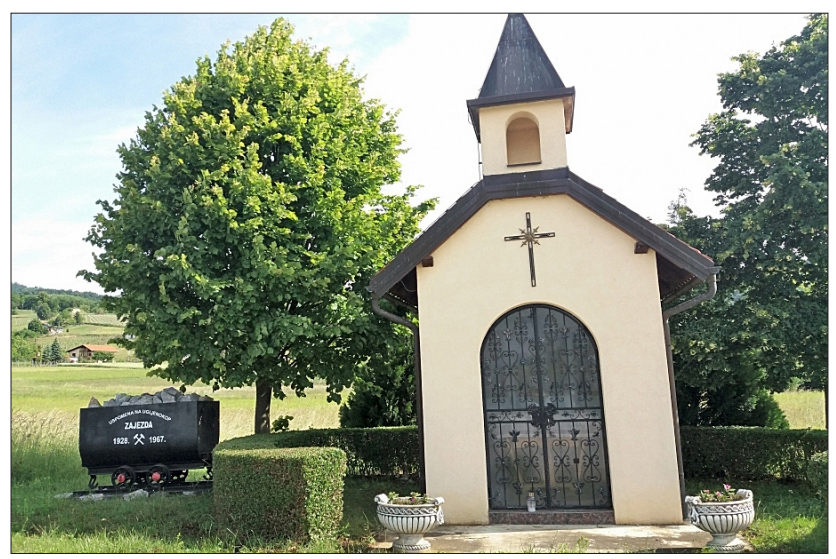

Figure 9: Chapel of St. Barbara and the Monument to the Zajezda Mine (by Briševac, Z.)

The oldest mining shaft in the mountain range of Bilogora is in Glogovac. In 1869, the Hawthorn Coal Mining Association was founded, and it received official concessions from the state in 1874 . Since then, exploitation was being conducted with more or less success until 1970, and when the production stopped, the mines were also shut down. Attempts of revitalization in the first part of the 1980s were not successful (Feletar, 1986). There has been a major economic change in the Bilogora region, which is still nostalgic about the mining and miners. The memory of better days has remained. Nowadays, Glogovac is empty and even neglected in some parts (Horvat, 2014).

Remains of mining buildings such as a loading bunker (see Figure 10) are reminiscent of the former mine. In 2008, the Tourist Board of the Koprivnica-Križevci County planned a cultural and educational evaluation of the mine in Glogovac. However, a mining sign and multilingual panel have not been set up thus far.

Some historical details have shown that the first underground coal mine in Međimurje was opened in Peklenica on June 5, 1870 (Mesarić, 2015). The exploi-

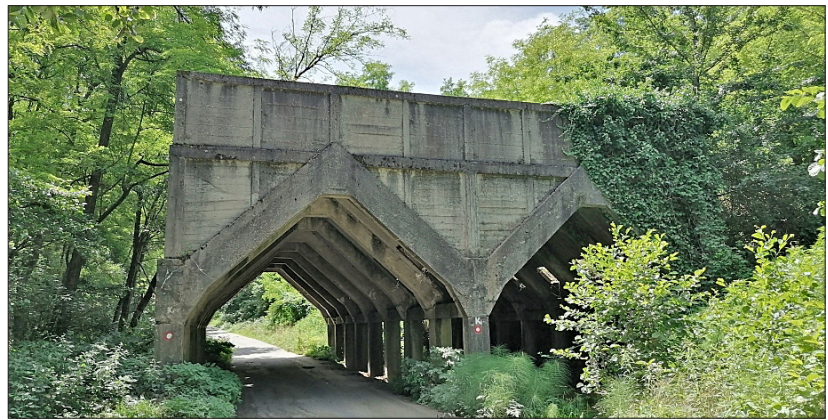

Figure 10: Remains of a coal loading bunker in Glogovac (by Briševac, Z.)

tation of coal has also been recorded in the village of Dragoslavec since 1918. The founder of the mine was Juraj Brlek (Požgan et al., 2019). In addition, it is known, for certain, that coal was mined in that region at the end of the First World War. A significant industrial exploitation of coal by open pit mining had been initiated by the entrepreneur Karlo Vargazon in Peklenica in 1919. After the Second World War, the socialist regime started to exploit coal. The mines were nationalized and merged into one company that was eventually called Međimurje Coal Mines. In the middle of the 20th century, the company was one of the largest coal producers in Croatia (Kalšan, 2006). Međimurje Coal Mines stopped working in 1972, and the company changed its activity (Požgan and Posedi, 2019). Anthropogenic relief form elevations (locally called "halde") and depressions (locally called "grabe") were created due to many years of mining activity in a larger area of Mursko Središće (Mesarić, 2015; Buntić, 2020). Although the city itself was called the City of Miners, the actual management of mining geoheritage is insufficient today. The greater number of "haldes" situated near villages are endangered due to unrecognized values and a significant anthropogenic impact. The conservation of geomorphological sites within the framework of the Nature Protection Act is a prerequisite for their physical protection, restoration, tourist benefits and their contribution to the sustainable development of the region (Mesarić, 2015).

Coal was also mined outside of three dominant regions, for example, in Dalmatia in the area of Siverić and Drniš. The exploitation of coal dates back to the Venetian Republic, but mining achieved remarkable value during the Austro-Hungarian Empire. There are still some individual traces in the form of forgotten tracks, like an abandoned devastated workshop, masonry shells of the substation and barely noticeable, mostly unmarked, and unprotected entrances to the once famous pits, even named after imperials and royals. However, mining is being gradually erased from the memory of today's generations because it is not a part of their life. Mining has been neglected. Additionally, the facts about it are overshadowed by human negligence and further desecrated in the Croatian war of independence in the end of the 20th century (Tarle, 2016). 
Lignite was also explored and exploited in the last half of the 19th century and in the first half of the 20th century near Kravarsko and its wider surroundings, the hills of Vukomeričke Gorice until the end of the Second World War. At that time, the mine and its equipment were devastated. The only trace of the mine has been preserved in the evidence related to the purchase of the mine, namely in the Purchasing Contract, government acts and other documentation, mining permits, mining profiles, etc. (Šebečić, 2010).

\subsection{Metal mining}

Although Croatia does not have any metal extraction site today, it is worth mentioning that the roots of mining and metallurgical traditions lie deep in the past. The first traces of copper casting in Croatia were recorded nearly 6000 years ago, and they are related to the artefacts of the Vučedol civilisation in the vicinity of the town of Vinkovci. The Celts had a significant impact on mining in Croatia since they initiated the production of iron after the town of Sisak had been established in the Pannonian part of Croatia. After the Roman conquest, mining and metallurgy had been significantly developed (Fabijanec and Vasiljević, 2017). In the Middle Ages, many Croatian aristocratic families had built their wealth on the intensive exploitation of metal ores, but this activity stopped at the beginning of the industrial age due to the unprofitable nature of small deposits.

In the past, there was a considerable extraction of metals due to the mining of silver, lead, zinc, copper, iron and aluminum. However, there are no potential metal ore deposits today. Amongst old underground mining sites, only two have been revitalized to some extent and presented as a part of cultural and mining heritage sites to visitors and have been used in geo-tourism. These old mines, where local people used to mine precious metals in the past, are the St. Barbara copper and iron mines in Rude village near Samobor and the silver mine Zrinski located on Medvednica. Mines were partially revitalized by the local community and different associations or public institutions. The main aim of revitalization was the preservation of old mining traditions. St. Barbara mine is maintained by the local community and the Croatian Folklore Ensemble Oštrc (URL12; Vrkljan, 2019). The old Zrinski mine is maintained by the Nature Park Medvednica (URL13; Vrkljan, 2019). There is one interesting old mine with a potential for revitalization by the local community in cooperation with the Tourist Office and it is called Kraševski zviri. This old mine is near Ivanec, where zinc was mined (Jagetić Daraboš, 2017).

In addition, the rich history of mining is especially evident in the whole area of Trgovska gora, where metal mining was first recorded during the Roman and Illyrian times. Today, the remains of the blast furnace from the 19th century still exist in Bešlinec. The blast furnace that was closed in 1942 represents industrial heritage today.
The mining of iron and copper, as well as lead-silver ores, was exceptionally active during the Middle Ages and the reign of the family Zrinski that built the fortress Gvozdansko (named after iron) in 1488. The same family was affiliated with the Zrinski mine on Medvednica Mt. (Laszowski, 1944; Šebečić, 1998; Šebečić, 2000).

Bauxite was also mined in Croatia. The first bauxite mines in the world were opened in the first half of the 16th century in the Croatian area of Istria, namely in the valley of the river Mirna below Sovinjak castle. The first scientific description of bauxite ore was written in 1808 about Sovinjak bauxite (Turini, 1808). The centre of this mining area is the Minjera site, which could be of worldwide importance in the future, in terms of marking the exploitation of bauxite (Marušić et al., 1993). In the area of Drniš, the Kalun bauxite mine was the deepest bauxite mine in the world during the cessation of exploitation. The exploitation ceased in 1963 because the mine was filled with underground water (Tarle, 2016).

\subsection{Petroleum exploitation}

The first records of petroleum utilization in Croatia date back to the early Middle Ages. Dubrovnik's merchants already mentioned tar in the 12th century. The physician Pietro Andrea Mathioli from the city of Gorizia, published the book "Commentarii in sex libros Pedacii Dioscoridis Anazarbei de Medica materia" in Venice in 1565 with the most important details. Oil digging near the island of Hvar, in Panonia and not far from the Neretva River was mentioned in the book as well. The travelogue of Albert Fortis in his book "Viaggio in Damazia" published in 1774 describes the bitumen mine on the island of Čiovo and the site near Škrip on the island of Brač, later known as Minjera mine (Kanajet et al.,1995 and Šebečić, 1995), around Vrgorac and near Sinj. The first exploration permits were granted as early as 1855 , and an organized oil production with a valid permit was recorded in 1856. Count Juraj Feštetić started with legal oil production in several shallow wells (4 to 10 meters deep) in the Medimurje area.

Due to a long tradition of oil exploitation, Međimurje can be considered as one of the oldest oil exploitation areas in the world. The most significant oil deposits in history were the oil fields in Peklenica and Selnica. These well sites have recently been transformed into heritage parks (see Figure 11 and Figure 12).

Almost simultaneously, research has begun in the area of Voloder, Mikleuška in the Moslavina region (Central Croatia), Paklenica near Novska and in Baćindol near Nova Gradiška (Žgaljić, 1984).

In the middle of the 19th century, the Polish pharmacist Ignaz Lukasiewicz discovered the kerosene lamp. Lighting with kerosene lamps was introduced in the cities of the Austro-Hungarian monarchy of which Croatia was also a part of at that time. The first major mining facility built in the Moslavina region was the Martin pe- 


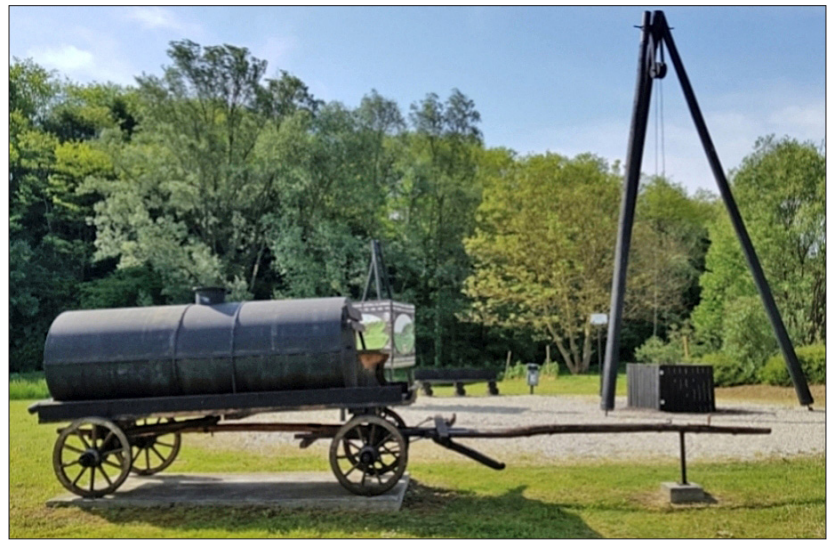

Figure 11: Peklenica petroleum heritage park (by Brkić, V.)

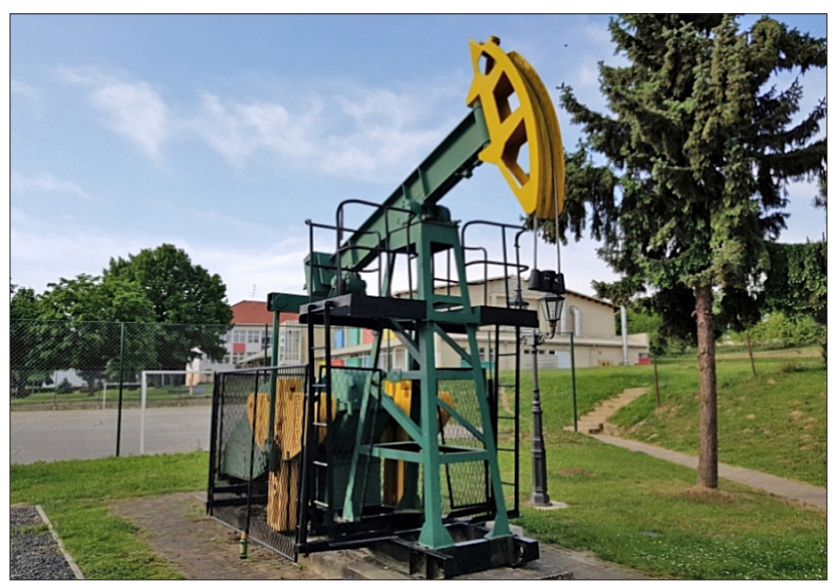

Figure 12: Selnica petroleum heritage park (by Brkić, V.)

troleum shaft (Velić et al., 2012), from which oil was being extracted in the period from 1854 to 1943 (see Figure 13). The 72-meter-deep Martin shaft was once the largest in the Austro-Hungarian Empire. Oil was even used to illuminate the city of Vienna (Novak-Zoroe, 2013).

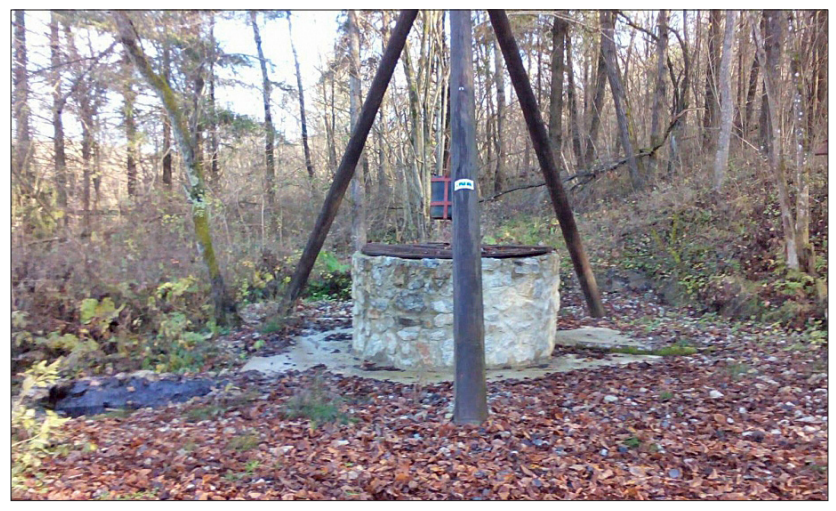

Figure 13: Martin petroleum shaft (by Brkić, V.)

In the area between the Drava and the Sava rivers, the remains of exploration and production have been recorded at a dozen localities, mostly in places where natural oil spills have been observed earlier (Križ et al., 2008).
An intensive growth in the exploration and production of oil and gas in the Republic of Croatia was initiated in 1952 in the Pannonian basin.

The historical outline of oil and gas exploration and production, which also had an impact on Croatia, would not be complete without mentioning Antun Lučić, the most famous Croatian oil expert who worked in the United States of America. At the beginning of the 20th century, he made a revolution in petroleum engineering by introducing rotary drilling, drilling mud (drilling fluid) and other innovations. In 1936, the American Institute for Geological and Metallurgical Investigations awarded the Gold Medal Prize named after Anthony F. Lucas for development in the field of oil and gas exploration and production. A museum with a granite obelisk was built in honor of the explorer Lučić, with the following inscription: "A new era in the civilization began on this spot on the tenth day of the twentieth century" (McBeth, 1998).

\section{Discussion}

This paper has addressed a wide area related to the history of the mining and petroleum industry. If we want to connect mining, petroleum, and geological heritage, then the term "geotechnological heritage" can be used. The expression is related to a permanent bond between mining, petroleum and geology. It stems from the Greek word "geo" (i.e. earth), "tekhne" (i.e. skill, mastery, ability, or craft) and "logia" (i.e. knowledge, science). Although such an expression has not been mentioned yet in literature, and it is used for the first time in such context, there has not been a justified argument for its non-use in terms of preserving the specific industrial heritage. In Croatia, the expression "geotechnological heritage" can be used because it is recognizable in our circumstances. However, each part of the heritage has its own unique characteristics, so they should be taken into account.

The broadest segment of geotechnological heritage is a geological one because it presents the natural structure of the underground. The mining and petroleum industry would not exist without geology, which represents a fundamental science. In addition, through mining activity, the underground geological nature becomes more visible and accessible. This indicates a direct connection between mining and the necessary knowledge of nature and geology. The connection is also visible from the UNESCO World Heritage List (URL1). It is essential to emphasize that mining, and geological heritage are mutually interconnected, but they are also linked with cultural heritage in general. Croatia has nurtured an old tradition of raw material exploitation (particularly quarrying). Many old quarries, mines or industrial remains still exist in traditionally mining regions like Istria or on the islands of Brač and Korčula.

The exploitation of mines and raw materials has played an important role in the economy of some Croa- 
tian regions. Nowadays, they do not play an essential role in the economy, but their remains still exist. However, there has always been a negative perception of the exploitation of mines due to terrible working conditions in the past, but also due to its negative impact on the environment in modern times (Petlovanyi et al. 2019). Heritage in terms of adopting certain patterns of behavior is also worth preserving and protecting. Socially isolated miners had always been exposed to various dangers in order to ensure a better standard of living for society. They had also built a type of solidarity, much like soldiers in a war (Freese, 2006). As time goes by, people who used to work in mines pass away and thus solidarity with former mining areas also weakens. Therefore, efforts regarding the collection and writing down of verbal stories about the life of miners are very precious (Horvat, 2014).

There are various approaches to the revitalization of mining heritage, as can be seen in the case of the town of Labin. After the mine was closed, the "Art Association Labin Art Express" was established and it has come up with the idea of building an "Underground City" with all of the facilities normally found in a city. Lately, the town administration of Labin has initiated the projects KOVA, MIN-HER and MINE TOUR, which are primarily cultural projects, but none of these projects have been realized so far. However, the cultural and commercial aspects of the projects must be harmonized. It is easier for a local administration to take into account a cultural aspect, but it should not be overrated. On the other hand, commercial facilities are equally relevant because the population must earn for living. The primary challenge is to achieve synergy between all the stakeholders in the revitalization of geotechnological heritage. Clear legislation would help overcome these challenges.

In Croatia, examples of the protection and local utilization of mining, petroleum and connected geological heritage are not widely known compared to European ones. If regions and types of mineral resources are taken into account, most elements of cultural heritage are present in coastal regions and are related to the extraction of natural building stone, which was used for building old cities along the Adriatic coast, monuments and cultural heritage buildings. In historical regions where coal was exploited, such as Istria, Zagorje, Međimurje and Bilogora, there are also places where mining cultural elements can be found. Furthermore, there are several places near Zagreb where metal ore was exploited during the Middle Ages, such as the St. Barbara mine near Rude, the Zrinski mine on Medvednica Mt. and also Trgovska gora.

Freese (2006) points out, "When we think of oil, it associates us with sudden wealth, while coal associates us with poverty and disappointment." So, petroleum heritage has a different perception because it did not require difficult working conditions as in mines where the predominantly poor population had been worked. Unfortunately, Croatia has not had any petroleum museum yet.
The Croatian company INA Plc. has rich archives with plenty of equipment and documentation related to oil and gas exploration and production, which could become a part of a museum exhibition. Therefore, a Petroleum museum in Ivanić Grad is planned to be found as a first petroleum museum in Croatia, which should present a centenarian cultural and monumental heritage of the oil industry.

The research which was done for the purpose of making this paper has also shown the existence of identical names for remote locations. In coastal area, these names are of Italian origin "pegola nera" (which means black resin) and "Minjera" (which means mine). There is Minjera on the island of Brač as a former bitumen mine and Minjera in Istria, which was a bauxite mine. A similar thing is with the name "Peklenica" near Mursko Središce and "Paklenica" near Novska. The word "Pekla" means an oil outgrowth. This is very interesting, but it must be taken into account because the same name cannot be used in the process of branding and increasing the web visibility of a site. The same names can confuse potential foreign visitors.

The world and way of living are constantly changing, but these changes are often connected with raw materials, including hydrocarbons and its mining from the Stone Age to the Modern Age. In addition, mining may be considered as a temporary activity in some places, and the possibility of the reuse of old mines, oil and gas fields once they are closed, must be taken into account. Some of them may represent a precious heritage whether they have cultural and historical, or maybe geological or industrial (mining and petroleum) significance.

In terms of presenting industrial heritage, and thus geotechnological heritage, the ERIH organization has contributed a lot in that respect. ERIH has placed industrial heritage on the tourist map of Europe for better recognition. The tourist potential in Croatia is still unrecognized and insufficiently appreciated. It is essential to follow the example of other European countries (France, Poland, Germany, etc.) which are more oriented to their tourist attractions in various forms of tourism. Thus, geotechnological heritage has a great potential that must be recognized and used once mining activity has ceased. The site itself is the basis for further tourist activity and education. The key thing in terms of geotechnological heritage in Croatia is investment. Investment in projects that will be recognized, investment in advertising and promotion of geotechnological heritage and investment in sites that already represent good grounds for further progress.

\section{Conclusion}

The main emphasis in this paper is the review of Croatian geotechnological heritage. Such a term could be used for better recognition of mining, geological and petroleum heritage within the broader concept of industrial 
heritage. The most promising segment of geotechnological heritage is geological heritage that can be developed in areas with the old tradition of raw material exploitation, particularly quarrying and also in the field of nature protection.

One of the important problems identified that influences revitalization processes is lacking clearer legislation. Clear legislation would help in overcoming the challenges of various concepts of protection and revitalization and would encourage synergy of all stakeholders in the revitalization of geotechnical heritage.

Due to the unjustified but real negative perceptions of mining and post-industrial landscapes in general, the cultural preservation of mining heritage should also be based on intangible potentials such as mining traditions, customs, and unique local identities. Efforts to collect and write down verbal stories about the mining life need to be stepped up because people who have been involved in mining pass away and their testimonies disappear with them.

As the European experience and some of our cases show, these geotechnological heritage potentials can be carefully turned into cultural objects, historical events, local museums, industrial tourist routes or trails and many other examples of good practice. In addition, Croatia should present the cultural and monumental heritage of the oil industry in a unique thematic museum due to the long tradition in oil and gas production.

Croatia is recognized as a country with a relatively large number of sites where geotechnological heritage could be adequately presented. All places where mineral resources are now exploited could one day become places of protection and presentation of geotechnological heritage. One of the proposals to the Republic of Croatia, as a member of the European Union, is to make the most of the available funds for financing mining, geological and petroleum heritage to achieve more recognition in Central and Western Europe. It must be strongly emphasized that geotechnological heritage is more recognized and used in Europe than in Croatia.

\section{Acknowledgment}

This paper is supported by project "MineHeritage: Historical Mining - Tracing and Learning from Ancient Materials and Mining Technology" that is funded by the European Institute of Innovation and Technology (EIT), a body of European Union, under the Horizon 2020, the EU Framework Programme for Research and Innovation.

\section{References}

Bićanić, R. (1951): Doba manufakture u Hrvatskoj i Slavoniji 1750-1860 (The era of manufacturein Croatia and Slavonia 1750-1860). JAZU, Zagreb, 460 p. (in Croatian without English abstract)

Bogdan, A. (2018): Projekt obnove kulturno-povijesne baštine grada Stona (Project for the restoration of the cultural and historical heritage of the town of Ston). Građevinar, 69(10), 905-912. (in Croatian without English abstract)

Brgles, B. (2014). Odabrane teme iz paške povijesne toponimije. Sol, drvo, vjetar i voda: glavne značajke paškoga povijesnog okoliša u srednjem i ranome novom vijeku (Select ed topics of Pag historical toponymy. Salt, wood, the wind and water main features Pag historic environment in the middle and early modern age). Ekonomska i ekohistorija, 10, 1, 189-198. (in Croatian with English abstract)

Buntić, A. (2020): Rudarska geobaština Europe i Hrvatske (Mining Geoheritage of Europe and Croatia), Diplomski rad, Sveučilište u Zagrebu, Prirodoslovno-matematički fakultet, Zagreb, 55 p. (in Croatian - there is English abstract)

Buzov, M. (2009): The Ancient Quarries in Croatia: The Technology of Extracting Stone. IX. International Conference ASMOSIA, García-Moreno, A. G. Lapuente Mercadal, M. P. De Llanza, I. R. (eds.): Tarragona, 628-635.

Cambi, N. (2013): Herkul na Braču (Hercules on the island of Brač). Klesarstvo i graditeljstvo, XXIV, 1-2, 4-19. (in Croatian with English abstract)

Cheirchanteri, G. (2019): Industrial Cultural Heritage as an Alternative Tourism Model: Case study of the Wider Lavreotiki area in Southeastern Attica IOP Conf. Ser.: Mater. Sci. Eng. 603, 022001, https://doi.org/10.1088/1757899X/603/2/022001

Craig, J., Gerali, F., MacAulay, F., Sorkhabi, R. (2018): The history of the European oil and gas industry(1600s-2000s). GeologicalSociety, London, Special Publications, 465(1), $1-24$.

Crnković, B. (1991): The origin of the dimension stone of the Arena in Pula. The Mining-Geology-Petroleum Engineering Bulletin (Rudarsko-geološko-naftni zbornik), 3, 63-67.

Crnković, B., Jovičić, D. (1993): Dimension stone deposits in Croatia. The Mining-Geology-Petroleum Engineering Bulletin (Rudarsko-geološko-naftni zbornik), 5, 139-163

Didolić, P. (1957): Historijski brački kamenolomi (Historical Brač quarries). Brački zbornik, 3, Split, 98-106. (in Croatian without English abstract)

Donelli, I., Matijaca, M., Paduan, I. (2009): Ancient quarries on the eastern Adriatic coast with specific reference to the island of Brač (Croatia). IX. International Conference ASMOSIA, García-Moreno, A. G. Lapuente Mercadal, M. P. De Llanza, I. R. (eds.): Tarragona, 636-640.

Douet, J. (2019): The Heritage of the Oil Industry. TICCIH The International Committee for the Conservation of the Industrial Heritage, $75 \mathrm{p}$.

Fabijanec, S. F. Vasiljević, R. (2017): L'exploitation et le commerce des métaux en Croatie \& Slavonie médiévales - esquisse d'une recherche. Ekonomska i ekohistorija časopis za gospodarsku povijest i povijest okoliša, 12, 65-100. (in French with English abstract)

Feletar, D. (1986): Povijesni razvoj i suvremeno značenje vađenja ugljena na podravskoj Bilogori (The historical development and the contemporary of coal-mining in podravian part Bilogora). Radovi Zavoda za znanstveni rad Jugoslavenske akademije znanosti i umjetnosti, 1, 171-191. (in Croatian with English abstract) 
Fio Firi, K., Maričić, A. (2020): Usage of the Natural Stones in the City of Zagreb (Croatia) and Its Geotouristical Aspect. Geoheritage, 12:62, https://doi.org/10.1007/s12371-02000488-x

Freese, B. (2006): Coal: A human history. Arrow books, London, $340 \mathrm{p}$.

Gjivoje, M. (1970): Antikni kamenolomi na Korčulanskim otocima (Antique quarries on Korčula Island). Zbornik otoka Korčule, 1, 68-75. (in Croatian without English abstract)

Horvat, S. (2014): „Bilogorski rudnici“ Koprivnica (Pogon Bregi) 1960-ih i 1970-ih : antropološki pristup (,, The mines of Bilogora" Koprivnica (Shed Bregi) in 1960s and 1970s). Podravski zbornik, 121-134. (in Croatian with English abstract)

HRN EN 12440 (2017): Prirodni kamen - Kriteriji za utvrđivanje nazivlja (EN 12440:2017) (Natural stone Denomination criteria (EN 12440:2017). Croatian Standards Institute, Zagreb, 107 p.

Inácio, N., Ferreira, T., Oliveira, M., Pinto, A.M.M., Relvas, J.M.R.S. (2013): The megalithism in Lousal: an example of valorisation of mining, geological and archaeological heritage. XIV Congreso sobre Patrimonio Geológico y Minero. Castrillón (Asturias), 2013. Libro De Actas Del Congreso. ISBN 978-99920-1-771-5. 765 - 776

Jagetić Daraboš, B. (2017): Knjiga rudarske i viteške mudrosti (A book of mining and chivalrous wisdom). Turistička zajednica grada Ivanca, 206 p. (in Croatian without English abstract)

Kalšan, V. (2006): Međimurska povijest (Međimurje history). Vlastita naklada, Zagreb, 490 p. (in Croatian with English abstract)

Kanajet, B., Sakač, K., Šebečić, B. (1995): Nekadašnji rudnik asfalta "Škrip" (The Former Asphalt Mine "Škrip" on the Island of Brač). The Mining-Geology-Petroleum Engineering Bulletin (Rudarsko-geološko-naftni zbornik), 7, 1, 87-95 (in Croatian with English abstract)

Kaźmierczak, U., Strzałkowski, P., Lorenc, M. W., Szumska, E., Peréz Sánchez, A. A., Baker K. A. C. (2019): Post-mining Remnants and Revitalization. Geoheritage, 11, 20252044, https://doi.org/10.1007/s12371-019-00408-8

Kišpatić, M. (1878): Slike iz rudstva, Kulturno-prirodopisne crtice (Mining Figures). Poučna knjižnica "Matice Hrvatske”, 230 p (in Croatian without English abstract)

Kovačević Zelić, B., Maričić, A., Burečić Šafran, M., Hrženjak, P. (2020): Kontinuitet kamenarstva i života s kamenom u Hrvatskoj (Continuity of stonemasonry and life with stone in Croatia). Godišnjak Akademije tehničkih znanosti Hrvatske 2019, 191-206 (in Croatian without English abstract)

Kozina, D. (2014): Radoboj. Općina Radoboj (Radoboj. Municipality of Radoboj.). Tiskara Velika Gorica. 448 p. (in Croatian without English abstract)

Križ, J., Weisser, M., Brkić, V., Domitrović, D., Ivković, Ž. (2008): Istraživanje i proizvodnja nafte i plina u Hrvatskoj i u inozemstvu (Oil and gas exploration and production in Croatia and abroad). Nafta, 59, 5, 261-267. (in Croatian without English abstract)
Kruczek, Z., Kruczek, M. (2016): Post-Industrial Tourism as a Means to Revitalize the Environment of the Former Oil Basin in the Polish Carpathian Mountains. Polish Journal of Environmental Studies, 25, 2, 1-6

Laszowski, E. (1944): Rudarstvo u Hrvatskoj 2 (Mining in Croatia 2). Hrvatska državna tiskara, Zagreb, 258 p. (in Croatian without English abstract)

Marović, G., Senčar, J., Kovač, J. and Prlić, I. (2004): Improvement of the radiological environmental situation due to remedial actions at a coal-fired power plant. Journal of Radioanalytical and Nuclear Chemistry, 261, 451-455.

Marušić, R., Sakač, K., Vujec, S. (1993): Four centuries of bauxite mining. The Mining-Geology-Petroleum Engineering Bulletin (Rudarsko-geološko-naftni zbornik), 5, 1, 15-20.

McBeth, R.S. (1998): Anthony F. Lucas- Pioneering the Gulf coast, INA-Oil industry Inc. Naftaplin-Zagreb, Revised and adapted edition, $75 \mathrm{p}$

Medunić, G., Rađenović, A., Bajramović, M., Švec, M., Tomac, M. (2016): Once grand, now forgotten: what do we know about the superhigh-organic-sulphur Raša coal?. The Mining-Geology-Petroleum Engineering Bulletin (Rudarsko-geološko-naftni zbornik), 31, 3, 27-45.

Mesarić, M. (2015): Zaštita i valorizacija rudarske geobaštine na primjeru Murskoga Središća (Protection and evaluation of mining geoheritage on the example of Mursko Središce) . Doktorska disertacija, Prirodoslovno matematički fakultet, Zagreb. (in Croatian - there is English abstract)

Mileusnić, M., Maričić, A., Hruškova Hasan, M. (2019): Croatian geological heritage related to historical mining and quarrying. European Geologist Journal, 48, 5-9

Novak-Zoroe, S. (2013): Hrvatski naftaši (Croatian oilmen). Hrvatska udruga naftnih inženjera i geologa, 619 p. (in Croatian without English abstract)

Parica, M. (2014): Tool Traces in the Classical Antiquity and Mediaeval quarries of Dalmatia as an Aid in the Chronological Definition of Individual Stages of Exploitation. Archaeologia Adriatica, 8, 1, 51-80.

Petlovanyi, M., Kuzmenko, O., Lozynskyi, V., Popovych, V., Sai, K., Saik, P. (2019): Review of man-made mineral formations accumulation and prospects of their developing in mining industrial regions in Ukraine. Mining of Mineral Deposits, 13, 24-38.

Petrić, H. (2013): Socioekonomski razvoj hrvatsko - slovenskog pograničja od kraja XVIII. stoljeća do Drugoga svjetskog rata - primjer ivanečkog i viničkog kraja (Socio-economic development of the Croatian - Slovenian borderlands since the late 18th century to World War II - an example of Ivanec and Vinica areas), Historia Varasdiensis, 3(1), 27-39. (in Croatian with English abstract)

Požgan, J., Posedi, I. (2019): Rudnici ugljena na području Međimurja i koprivničke Podravine nakon 1945. Godine (Coal mines in the area of Medimurje and Podravina region around Koprivnica after 1945), Podravina, 18(35), 156 -176. (in Croatian with English abstract)

Russell, B., Glicksman K. (2015): Recent work on Roman quarries near Korčula and on Brač. Vjesnik za arheologiju i historiju dalmatinsku, 108, 1, 223-244. 
Rybár, P., Hronček, P. (2017): Mining tourism and the search for its origins. Geotourism, 3-4, 27-66.

Šebečić, B. (1995): Povijest istraživanjai eksploatacije bituminoznih i kerogenih nalazišta Hrvatske (The History of the Exploration and Exploitation of Bituminous and Kerogenous Deposits in Croatia). The Mining-Geology-Petroleum Engineering Bulletin (Rudarsko-geološko-naftni zbornik), 7, 1, 97-130 (in Croatian with English abstract)

Šebečić, B. (1998): Knezovi Zrinski i Frankopani te njihova rudarska poduzetništva (The Counts Zrinski and Frankopani and their mining enterprises). The Mining-GeologyPetroleum Engineering Bulletin (Rudarsko-geološkonaftni zbornik), 10, 121-129. (in Croatian with English abstract)

Šebečić, B. (2000): O rudarskom poduzetništvu u Banovini (Hrvatska) (About mining entrepreneurship in Banovina (Croatia)). The Mining-Geology-Petroleum Engineering Bulletin (Rudarsko-geološko-naftni zbornik), 12, 99-124. (in Croatian with English abstract)

Šebečić, B. (2010): O povijesti istraživanja i eksploatacije vukomeričkih lignita - Ljudevit pl. Farkaš Vukotinović rudarski poduzetnik! (On the history of research and exploitation of Vukomerian lignites - Ljudevit noble Farkaš Vukotinović mining entrepreneur!). The Mining-GeologyPetroleum Engineering Bulletin (Rudarsko-geološkonaftni zbornik), 22, 1, 81-90. (in Croatian with English abstract)

Tarle, I. (2016): Drniško rudarstvo (Mining in Drniš), Godišnjak Titius, 9(9), 139-222. (in Croatian with English abstract)

Turini, P. (1808): Della preparazione dell'allume nella miniera di S. Pietro nel dipartimento dell'1stria. Stamperia di Antonio Curti q. Giacomo, Venezia, 67 p. (in Italian without English abstract)

Velić, J., Malvić, T., Cvetković, M. (2012): History of oil and gas production in the Croatian part of the Pannonian basin system, 2nd International Conference "Alpine Petrol 2012" on "Geology, Ecology and Petroleum Prospectives of the Carpathians and other Alpine Regions in Europe" / Kotarba, M. J. and Wrobel, A. - Krakow (eds.): Society of Research on Environmental Changes "Geosphere", 103-104.

Vrkljan, D. (2019) Zaštita hrvatske rudarsko-geološke materijalne baštine (Protection of Croatian mining-geological material heritage). Annual of the Croatian Academy of
Engineering, 2019(1):485-500. (in Croatian without English abstract)

Vujec, S. (1997): Istarski ugljenokopi od Krapna do Tupljaka (Coal mines in Istria from "Krapan" to "Tupljak"). The Mining-Geology-Petroleum Engineering Bulletin (Rudarsko-geološko-naftni zbornik), 9, 5-10. (in Croatian with English abstract)

Wirth, P., Cernic Mali, B., Fischer, W. (2012): Post-Mining Regions in Central Europe - Problems, Potentials, Possibilities, Oekom München, 274 p.

Žeger Pleše. I., Zwicker Kompar, G. (2020): Geobaština u Hrvatskoj - jučer, danas i sutra (Geoheritage in Croatia yesterday, today and tomorrow). Acta Geographica Croatica, 45/46, 1-13, https://doi.org/10.21861/AGC.2019.4546.01 (in Croatian with English abstract)

Žgaljić, J. (1984): Nafta na našem tlu. Razvoj naftne privrede (Oil in our area-Development of petroleum industry). Privredni vjesnik, Zagreb, 283 p. (in Croatian without English abstract)

\section{Internet sources:}

URL1: https://whc.unesco.org/en/list/?search=mining\&order $=$ country $($ accessed 23rd April 2020)

URL2: https://www.erih.net/ (accessed 14th May 2020)

URL3: https://mineheritage-project.eu/ (accessed 14th July 2020)

URL4: https://www.solananin.hr/en/home/

URL5: http://radboa.com/ (accessed 14th June 2020)

URL6: http://www.lae.hr/ (accessed 14th July 2020)

URL7: http://www.labin.hr/projekt-prenamjene-rudarske-bas tine-kova (accessed 24th May 2020)

URL8: http://www.minher.eu/index.php\#pocetna (accessed 24th May 2020)

URL9: https://www.mine-tour.eu/sl/o-projektu/ (accessed 24th May 2020)

URL10: https://www.arhitektura.hr/en/Projects/Public/Memo rial-center-Karlota-in-Rasa-Rasa (accessed 14th July 2020)

URL11: http://www.enciklopedija.hr/Natuknica.aspx?ID= 53615 (accessed 6th May 2020)

URL12: http://www.rudnik.hr (accessed 24 ${ }^{\text {th }}$ April 2020)

URL13: https://www.pp-medvednica.hr/en/tourist-offer/zrin ski-mine/ (accessed 24th April 2020)

\section{Author's contribution}

Zlatko Briševac (1) (Ph.D. in mining engineering, Assistant Professor at the Faculty of Mining, Geology and Petroleum Engineering, University of Zagreb) assembled and analyzed data of European heritage and collected historical data for description of the mining heritage. He wrote a chapter on Croatian coal mining. He contributed to discussion and conclusion. Ana Maričić (2) (Ph.D. in geological engineering, Assistant Professor at the Faculty of Mining, Geology and Petroleum Engineering, University of Zagreb) studied Croatian and European geological heritage sites, wrote about Stone quarrying and excavation of industrial minerals and metal mining, contributed to the discussion, and conclusion chapters. Vladislav Brkić (3) (Ph.D. in petroleum engineering, Asocciate Professor at the Faculty of Mining, Geology and Petroleum Engineering, University of Zagreb) analyzed Croatian and European petroleum heritage and contributed to the discussion and conclusion chapters. Vladi Bralić (4) (mag.ing.arh. director in Arhitektonsko-građevinski atelje d.o.o.) described the Memorial center Karlota in Raša and provided a graphic figure of project. 